\title{
TEXTUAL AND LINGUISTIC MEANS OF CONSTRUCTING THE VENERABLE IMAGE IN MEN OF FAITH HAGIOGRAPHIES ${ }^{1}$
}

\author{
Evgeniya G. Dmitrieva \\ Volgograd State University, Volgograd, Russia \\ Irina A. Safonova \\ Volgograd State University, Volgograd, Russia
}

\begin{abstract}
The paper provides some results of linguistic analysis of Men of Faith hagiography in synodal and modern periods of Russian hagiography, the Life of Saint Seraphim of Sarov and Optina elder Leonidas (schemamonk Leo), in particular. The authors focus attention on textual and language means that are used to present the image of the man of faith, educe some peculiarities of hagiographic scheme that is to describe the life of saint eldership. It has been stated that the canonical structure of the saint hagiography demonstrates some variations of its implementation in the texts that are referred to separated time periods thus contributing to a full coverage of the saint's image due to a partitive-scheme realization (with some toposes lacking), a transformed scheme (when toposes demonstrate various gradation in detalization), or may be expended (by including new toposes). In the men of faith descriptions the following word groups show regularities in co-occurrence: words that describe the intrinsic (unseen) world (emotive lexical units) or present relations with extrinsic (observed) world (perceptive lexis). The reliance of emotives to the object status is estimated as a tool that serves for presenting high emotional intensiveness and its reasons, coordination between quantitative markers of emotional states and their measurement is uncovered. The perception processes are defined as valuable for making the venerable image because the perceptive words definitely point to specificity of the object assumption, and altogether they show connection between the process of information perception and cognition.

Key words: hagiographic text, eldership, Venerable image, toposes, emotive lexical units, perceptive lexis, lexical semantics.

Citation. Dmitrieva E.G., Safonova I.A. Textual and Linguistic Means of Constructing the Venerable Image in Men of Faith Hagiographies. Vestnik Volgogradskogo gosudarstvennogo universiteta. Seriya 2, Yazykoznanie [Science Journal of Volgograd State University. Linguistics], 2018, vol. 17, no. 4, pp. 27-39. (in Russian). DOI: https:// doi.org/10.15688/jvolsu2.2018.4.3
\end{abstract}

\section{Ф ТЕКСТОВЫЕ И ЯЗЫКОВЫЕ СРЕДСТВА СОЗДАНИЯ ОБРАЗА ПОДВИЖНИКА В ЖИТИЯХ ПРЕПОДОБНЫХ СТАРЦЕВ ${ }^{1}$}

\author{
Евгения Геннадьевна Дмитриева \\ Волгоградский государственный университет, г. Волгоград, Россия \\ Ирина Александровна Сафонова \\ Волгоградский государственный университет, г. Волгоград, Россия
}

Аннотация. Статья посвящена проблеме воплощения в словесной форме уникальной картины мира этноса и его ценностных предпочтений. Материалом для изучения послужили жития Серафима Саровского и оптинского старца Леонида (в схиме Льва), относящиеся к синодальному и современному периодам развития русской агиографии. В центре внимания авторов находятся текстовые и языковые средства создания 
образов преподобных. Рассмотрены особенности реализации агиографической схемы преподобнического жития в житиях старцев. Установлено, что при сохранении канона преподобнических житий в разновременных агиографических текстах схема может использоваться в них частично (отсутствие отдельных топосов), трансформироваться (реализация топосов с разной степенью детализации) или расширяться (реализация дополнительных топосов), что способствует более полному раскрытию образа святого.

Обнаружена общность в использовании языковых единиц при описании преподобного: его внутреннего, «незримого», мира (эмотивная лексика) и взаимодействия с миром внешним, «зримым» (перцептивная лексика). Определена зависимость выбора эмотива от статуса характеризуемого субъекта, значимость высокой интенсивности эмоционального переживания и его причины, связь между количественными характеристиками эмоции и ее оценкой. В исследуемых текстах выявлены закономерности языковой экспликации восприятия информации об окружающем мире с помощью разных органов чувств; показана значимость глаголов зрительного восприятия в создании образа старцев; охарактеризованы возможности перцептивных глаголов выражать специфику протекания перцепции, зависящую от характера субъекта, и связь процесса восприятия с осмыслением информации, полученной с помощью органов чувств.

Ключевые слова: житие, старчество, образ подвижника, топосы, эмотивная лексика, перцептивная лексика, лексическая семантика.

Цитирование. Дмитриева Е. Г., Сафонова И. А. Текстовые и языковые средства создания образа подвижника в житиях преподобных старцев // Вестник Волгоградского государственного университета. Серия 2, Языкознание. - 2018. - Т. 17, № 4. - C. 27-39. - DOI: https://doi.org/10.15688/jvolsu2.2018.4.3

\section{Вводные замечания}

На протяжении длительного времени жития занимали особое место в системе жанров отечественной словесности. Агиографические произведения на русской почве стали создаваться со времени принятия христианской веры, с самого начала возникновения древнерусской литературы и играли важную роль в литературном и - шире - культурном процессе до XVII в. включительно. В XVIII в. развитие русской житийной литературы замедлилось, новые тексты почти не создавались [Владимир (Швец), Сорочан, 2015, с. 97], однако в XIX - начале XX в. ее развитие вновь активизировалось. Затем последовал сложный для религиозной жизни советский период, оценивая который можно говорить о перерыве агиографической традиции. Конец XX в. ознаменовался созданием большого количества агиографических текстов, прославляющих как новых святых, прежде всего новомучеников и исповедников Российских, так и подвижников прошлого (появилось большое количество новых изданий с житиями, жизнеописаниями или биографиями подвижников, см., например: [Жития новомучеников и исповедников..., 2005-2008; Жития святых..., 1984; Карпов, 2005]).

Характерной чертой житий является, по словам С. Бёш-Гайано, их «подвижность» (наличие множества различных версий: от про- стых вариантов до форм настоящей переработки), которая «уходит корнями в особенность “биографической” памяти, включающей не только жизнь, понимаемую в биологическом смысле, но и жизнь после смерти, то есть длительное "присутствие" святого в исторической действительности, выражаемое в приписываемой его мощам чудотворной силе (virtus)» [Бёш-Гайано, 2011, с. 507].

В этой связи особый исследовательский интерес приобретает сопоставление в разных аспектах современных житийных текстов с житиями предыдущих периодов. В качестве источников для такого сопоставления нами были избраны жития преподобных Серафима Саровского и оптинского старца Леонида (в схиме Льва), относящиеся к синодальному и современному периодам развития русской агиографии.

Жития преподобных представляют собой самый распространенный тип агиографических текстов [Руди, 2006, с. 431]. Преподобный - это разряд святых, подвиг которых заключался в монашеском подвижничестве. Монашеская аскеза как тип святости предполагает отказ от мирских привязанностей, забот и стремлений и выбор следования Христу, поста и молитвы как основы жизнедеятельности [Живов, 1994, с. 81]. Старчество же как особая, высшая форма церковного служения стало уникальным явлением в истории России XIX века. Оно, «как всеобъемлющее 
делание, соединяет в себе все добродетели преподобных подвижников» [Ненароков, 2017, c. 7-8], «старческое руководство есть путь, которым старец-наставник ведет своих духовных детей к совершенствованию в духовной жизни» (ЖСЛ 2, с. 40).

В статье представлено сопоставление указанных житий с целью определить роль реализованных в них топосов в создании образа святых и выявить особенности использования языковых единиц при описании внутреннего, «незримого», мира преподобного (эмотивная лексика) и взаимодействия преподобного с миром внешним, «зримым» (перцептивная лексика).

\section{Реализация агиографической схемы преподобнического жития в житиях старцев}

Любая интерпретация житийного материала, как отмечает В.М. Живов, требует предварительного рассмотрения того, что относится к сфере литературного этикета. Это предполагает изучение литературной истории житий, их жанров, установление типичных схем их построения, стандартных мотивов и приемов изображения и т. д. [Живов, 1994, с. 9].

Отводя особое место в русской агиографии преподобническим житиям, Т.Р. Руди отмечает, что в них сформировалась самая разнообразная и разработанная литературная топика [Руди, 2006, с. 431], и выделяет в корпусе русских монашеских житий XI-XVII вв. цепь образующих единую систему топосов, состоящую из 26 элементов. Наложение данной схемы на изучаемые нами тексты показало, что в рассматриваемых житиях представлены различные вариации и сочетания ее элементов.

Анализируемые жития подтверждают наблюдение Т.Р. Руди о том, что «важнейшим типом топики монашеских житий являются топосы подражания (и/или уподобления) ангелам - imitatio angeli» [Руди, 2006, с. 434]. Так, в житии Серафима Саровского находим:

(1) Принявъ новое имя Ангельское, онъ отвра-

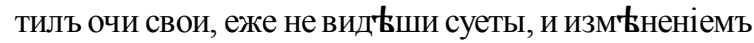
Божественнымъ, направиль путь свой внутреннимъ вниманіемъ и умнымъ Боговидтніемъ къ в'ъчному солнцу правды, Христу Богу, имя Коего носиль онъ непрестанно въ сердц' и устнахъ своихъ (ЖСС 1, с. 9).

Среди отмеченных топосов стабильность реализации обнаруживает топос «прохождение святым в монастыре различных служб», он представлен в каждом из четырех текстов:

(2) По вступленіи въ обитель проходиль онъ разныя послушанія, какъ-то: будильщика, просфорника, занимался столярною работою, и, по обычаю оной Пустыни, им'ль келейное занятіе рłзать кипарисные кресты. При построеніи въ то время больничной церкви, онъ изъ усердія сдълалъ престоль своими руками изъ кипариса (ЖСС 1, с. 8 );

(3) Кроме того, что этому старцу Прохор должен был прислуживать, он исполнял и другие послушания: в хлебне, в просфорне, в столярной, как пономарь (ЖСС 2, с. 8);

(4) В часы отдыха Прохор занимался работой: искусно вырезал из кипарисного дерева крестики для раздачи их богомольцам. Он был вообще искусен в столярничестве, так что в одном из списков расписании иноков назван «Прохор-столяр». У частвовал он также в общих трудах-послушаниях братии, состоявших в сплаве леса, заготовке дров (ЖСС 2, с. 9);

(5) Бо́льшихъ подробностей о первоначальной монашеской жизни о. Леонида мы не знаемъ. Изв ‘ссто только, что, живя въ монастырњ, онъ проводиль дни свои въ непрерывныхъ трудахъ, подавая собою всъмъ братіямъ примњръ искренняго послушанія (ЖСЛ 1, с. 8);

(6) Ревностно принялся молодой послушник за монастырские труды, подавая братии пример послушания и трудолюбия (ЖСЛ 2, с. 36);

(7) И здесь, как и в Оптиной, он проводил дни свои в непрерывных трудах, подавая всем братиям пример искреннего послушания (ЖСЛ 2, с. 37).

Как видно из приведенных фрагментов, степень детализации описания трудов подвижника может разниться, но автор жития всегда подчеркивает усердие святого, его ревностное желание трудиться не покладая рук.

В результате сопоставления разновременных житий обнаружены топосы, которые реализуются только в текстах одного из периодов. Так, во всех проанализированных текстах дано описание родителей святого. Однако если в текстах XIX в. подчеркивается «обычность» этих людей: 
(8) Отецъ его быль Курскій купецъ Исидоръ, по прозванію Мошнинъ, мать Агаөія. < .. > Какъ при жизни своей онъ [отец] занимался строеніемъ церквей, такъ и умирая оставиль, начатое имъ въ городњ Курск'十, созиданіе каменнаго храма во имя великаго Чудотворца, Преподобнаго Сергія, на попеченіе жень своей Агавіи, подъ надзоромъ которой въ посльдствіи времени оное и довершено (ЖСС 1, c. 5);

(9) Родители его были простые карачевскіе граждане, по фамиліи Наголкины (ЖСЛ 1, с. 7),

то в современных текстах реализуется топос благочестивых родителей:

(10) Происходил он из семьи богатого и именитого курского купца Исидора Мошнина, имевшего кирпичные заводы и бравшего подряды на постройку каменных зданий, церквей и домов. Он был известен как чрезвычайно честный человек, усердный к храмам. <..> Агафия Мошнина была еще более благочестивой, чем ее муж. Особенной ее чертой, которая впоследствии так резко отличала и ее великого сына, - было милосердие (ЖСС 2, с. 3);

(11) Родители его были простые благочестивые граждане мещанского сословия по фамилии Наголкины. Сына они воспитали в страхе Божием, в добродетели, честности и целомудрии (ЖСЛ 2, с. 35).

Топос оплакивания преставившегося подвижника реализуется только в текстах XIX века:

(12) Всњ, будучи поражены симъ извњстіемъ, скорбъли о разлук' съ таковымъ доблественнымъ подвижникомъ, который былъ примњромъ всей братіи и служиль украшеніемъ обители (ЖСС 1, с. 31);

(13) Хотя въ монастырњ н中тъ обыкновенія

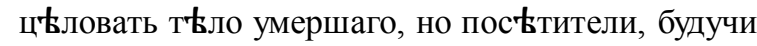
побъждены великою любовію къ почившему, во продолженіи литургіи и отпьванія, непрерывно ц'ъловали его руку со слезами (ЖСЛ 1, с. 176).

Топосы могут быть реализованы в житиях с разной степенью детализации. Об этом свидетельствует, например, сопоставление параллельных мест текстов жития Серафима Саровского, повествующих об аскетическом подвиге святого:

(14) По вступленіи въ жизнь отшельническую, т中лесныя его упражненія состояли въ воздтлываніи градъ для сажденія овощей, также въ приготовленіи дровъ для топленія келіи (ЖСС 1, с. 12);
(15) Внешние труды его состояли в заготовлении дров и топке кельи; впрочем, часто, чтобы томить себя, он терпел в келье мороз. Летом он обрабатывал огород, который удобрял мхом, собираемым на болоте. Во время этой работы он иногда обнажался до пояса, и множество насекомых безжалостно жалили его. Тело опухало, покрывалось запекшейся кровью, а он терпел (ЖСС 2, с. 15-16).

Некоторые топосы могут быть представлены в житии одного из старцев. Только в житии Серафима Саровского реализован «мотив божественных знамений, до рождения святого и/или в раннем младенчестве свидетельствующих о его избранности и посвященности Богу» (формулировка Т.Р. Руди: [Руди, 2006, c. 497]). Предваряя повествование о падении маленького Прохора с колокольни, чудесном его спасении и о чудесном его выздоровлении после поклонения иконе Богоматери, автор жития пишет:

(16) Особое промышление Божие о Прохоре выразилось в двух событиях его жизни (ЖСС 2, с. 4).

В житии Серафима Саровского XIX в. также есть указание на божественную природу этих событий:

(17) Благочестивая мать усмотрфла въ семъ особенное дьйствіе Промысла Божія, сохранившего отрока... (ЖСС 1, с. 6);

(18) Оть сихъ благодатныхъ дьйствій и чудес-

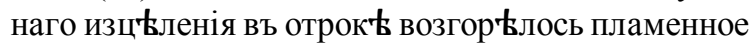
усердіе къ Господу Богу и Спасу нашему Іисусу Христу и Пречистой Его Матери (ЖСС 1, с. 7).

Топос обучения святого грамоте обнаруживается только в житиях Серафима $\mathrm{Ca}-$ ровского:

(19) По времени отрокъ Прохоръ отданъ быль для обученія чтенію и письму. Онъ былъ прильженъ и показываль остроту ума (ЖСС 1, с. 6);

(20) Когда его стали учить церковной грамоте, он принялся за дело с большой охотой, быстро преуспевал в учении... (ЖСС 2, с. 5).

В жизнеописаниях преподобного Льва этот топос не реализуется, но подчеркивается знание подвижником жизненных реалий:

(21) Въ молодости Левъ Даниловичъ Наголкинъ занимался торговыми дьклами, и въ должности 
купеческаго прикащика дњлаль часто большіе и дальніе разъ Россію; им 中ль сообращеніе съ людьми всЊхъ сословій, и чрезъ это еще въ миръ пріобрьлъ большое знаніе людей и опытность... (ЖСЛ 1, с. 7);

(22) Одаренный от Бога прекрасной памятью, любознательностью и сообразительностью, он, еще живя в миру, приобрел глубокое знание людей и опытность (ЖСЛ 2, с. 35-36).

Некоторые из топосов, выделенных T.P. Руди, в житиях преподобных старцев Серафима Саровского и Льва Оптинского не реализуются. Это брачный топос и мотив испытания отрока игуменом монастыря. Кроме того, тексты житий практически не содержат сведений о детстве подвижников. Полностью отсутствует эта информация в рассматриваемых житиях преподобного Льва, а в современном тексте жития Серафима Саровского читаем:

(23) К сожалению, о его детской поре сохранилось очень мало сведений. Он рос тихо, в обстановке исконно русского благочестия, и, можно сказать, все заветнейшее, лучшее русского народа, всю высокую его духовность, всю заботу и думу его о спасении, о вечности мало-помалу впитал в свою душу от того, что уже в ней не стало места иной заботе, иной думе (ЖСС 2, с. 4).

Важным результатом наблюдения над текстами разновременных житий считаем выявление случаев, отражающих развитие системы топосов, выделенной Т.Р. Руди: обнаружены примеры переосмысления и добавления топосов. Так, топос «плач родителей о сыне как о мертвом, поиски отрока и безуспешные попытки вернуть его к жизни в миру» (формулировка Т.Р. Руди: [Руди, 2006, с. 497]) в житии Серафима Саровского находит принципиально иную реализацию - мать святого, понимая высшее предназначение своего сына и принимая его выбор, не препятствует его уходу в монашество:

(24) Умная и благочестивая мать Прохора сердцем чуяла, что не жилец ее мальчик в миру, что иная ждет его доля. Вообще в отношении Агафии Мошниной к своему сыну мы видим полную противоположность тому, как относилась к преподобному Феодосию Печерскому тоже по-своему любившая его мать <...> Умная и благочестивая Агафия Мошнина поступила не так. Как мудрая христианка, она поняла, что пожертвовать сыном, без ропота уступив его Богу, будет угодной Ему жертвой, и что Бог всякому, ищущему Его, силен дать такое счастье, перед которым ничто вся слава, счастье и благополучие мира. И вера ее оправдалась (ЖСС 2, с. 5-6).

Анализируемые жития содержат дополнительные топосы: выбор обители, смерть наставника, переход в другую обитель, стремление к уединению, принятие старчества как духовного подвига:

(25) По-прежнему, о. Серафим искал пустыни для уединенной молитвы: вечером уходил в лесную келью и, проведя там ночь в молитве, к утру возвращался в Саров (ЖСС 2, с. 14);

(26) Отец Серафим заботливо ходил за умирающим наставником и благодетелем своим и горько оплакивал его (ЖСС 2, с. 15);

(27) Оплакав и предав земле тело любимого отца, преподобный Лев оставил обитель и некоторое время пробыл в Площанской Богородицкой пустыни (ЖСЛ 2, с. 39).

Перечисляя духовные подвиги старца, автор жития упоминает «усиленный пост» (ЖСС 2, с. 9), почти беспрерывное служение: ночи на воскресенья и большие праздники проводил все в молитве (ЖСС 2, с. 11), столпничество (ЖСС 2, с. 19), молчальничество (ЖСС 2, с. 23), затворничество (ЖСС 2, с. 24), старчество (ЖСС 2, с. 26).

Итак, анализ житийных текстов позволяет говорить о сохранении канона преподобнических житий в синодальных и современных агиографических текстах, хотя агиографическая схема в них может использоваться частично, трансформироваться или расширяться, способствуя более полному раскрытию образа святого.

\section{Эмотивные лексемы как средство характеристики преподобного}

Рассматривая художественно-изобразительные особенности произведений агиографического жанра, С.А. Аверина отмечает, что «в этом жанре, может быть, ярче, чем в каком-либо другом, прослеживается связь языковых средств (их выбор) с идейно-образным содержанием произведения» [Аверина, 1991, c. 9]. Жития накапливают опыт создания пси- 
хологических портретов, инструментарий приемов психологического анализа, «раскрытия внутреннего мира человека в его повседневном поведении» [Адрианова-Перетц, 1964, с. 42].

Особую роль в выражении нравственнорелигиозного идеала в агиографическом тексте играет лексика эмоций. Это обусловлено тем, что указания на психологические состояния человека, его чувства, эмоциональные отклики на события внешнего мира, способствуют созданию общей эмоциональной атмосферы повествования, делающей изображаемое более близким и понятным читателю, личностно переживаемым.

Предпринятое нами ранее исследование функционирования эмотивных лексем в древнерусских и старорусских житиях показало, что основная их функция - характерологическая. В нашей работе под характерологической функцией языковых единиц понимается употребление их в речи (тексте) с целью описания и характеристики людей, предметов и явлений действительности [Дмитриева, 2011, c. 44]. К факторам, определяющим специфику реализации характерологической функции, относятся: 1) статус характеризуемого субъекта (святой / обычный человек); 2) характер обозначаемой глаголом эмоции (положительная / отрицательная / нейтральная) и ее интенсивность (низкая / средняя / высокая); 3) причина эмоционального переживания.

Использование эмотивов в исследуемых нами житиях преподобных старцев обнаруживает общность, которая проявляется прежде всего в том, что статус характеризуемого субъекта связан с характером обозначаемой лексемой эмоции. Так, с подвижниками практически всегда связаны положительные эмоции, которые они переживают сами или вызывают у окружающих, например:

(28) Старец благословил всех окружавших его и сказал: «Ныне со мною будет милость Божия». После сих слов начал он веселиться духом и радоваться сердцем, и хотя испытывал тяжкие телесные страдания от болезни, но не мог скрыть ощущаемой им духовной радости, и лицо его начало все более и более светлеть (ЖСЛ 2, с. 49).

Наибольшей частотностью среди выявленных в житиях эмотивов обладают лексемы с корнем -люб- (любовь, любимый, воз- любленный, любовно и др.), употребленные в разнообразных сочетаниях с лексическими единицами, обозначающими Всевышнего, людей, предметы, локусы:

(29) Съ горящимъ усердіемъ онъ началъ подвизаться о приближеніи любовію ко Господу, и дьятельнымъ образомъ узналъ, что любовь возвышаетъ умъ нашъ къ Богу... (ЖСС 1, с. 9);

(30) Преподобный обрадовался приходу своего возлюбленного наставника как обретению великого сокровища (ЖСЛ 2, с. 38);

(31)... и возбуждалъ ихъ къ любви любовію своею. Впрочемъ, не смотря на его любовь ко всњмъ, онъ былъ для нЊкоторыхъ тяжекъ къ вид Łнію... Но и съ ненавидящими его онъ былъ миренъ, обходился кротко и любовно (ЖСС 1, с. 27);

(32) И теперь он должен был в оставшиеся ему семь лет жизни излить на русский народ все сокровища своего опыта, всю силу своих молитв, всю великость своей любви (ЖСС 2, с. 26);

(33) Пробыв пять месяцев в Сарове, о. Серафим вернулся опять в любимую свою пустынную келью (ЖСС 2, с. 21).

Употребленные в житиях лексемы, выражающие отрицательные эмоции, характеризуют подвижников положительно:

(34) «Кто нас оскорбит словом или делом, и если мы переносим обиды по-евангельски, учил он, - вот и вериги наши, вот и власяница» (ЖСC 2, c. 24).

Глагол оскорбить имеет значение «крайне обидеть, унизить кого-либо; уязвить, задеть в ком-либо какие-либо чувства» (БТСРЯ, c. 729) и называет процесс эмоционального воздействия, результатом которого является отрицательное чувство высокой степени интенсивности, на что в контексте указывает отождествление его с веригами и власяницей. Хотя, безусловно, характеризовать негативно данная лексема всегда будет лицо, инициирующее данную эмоцию, а не субъект эмоционального переживания, но в приведенном контексте заслуживает внимания именно то, что старец преодолевает в себе порождаемую внешним влиянием сильную отрицательную эмоцию.

Обычные люди (и миряне, и священнослужители) могут испытывать как положительные, так и отрицательные эмоции, например: 
(35) Но, видя, что он вроде мертвого, связав ему руки и ноги, бросили его в сенях, а сами кинулись в келью, где обшарили все углы, сломали даже печь, все надеясь отыскать деньги. Но нашли лишь икону да несколько картофелин. На них напал страх, и они убежали (ЖСС 2, с. 20).

Признаком, по которому миряне противопоставлены святому, становится причина эмоционального переживания. Ср. надеясь отыскать деньги в (35) и:

(36) После этого видения он отказался от какой бы то ни было врачебной помощи, говоря, что всю надежду возлагает на Господа и Богоматерь (ЖСC 2, c. 21).

Особенность в употреблении эмотивных лексем проявляется в выражении ими высокой интенсивности эмоционального переживания. Как и в текстах более ранних периодов, особенно часто для ее передачи используются уточнители образа действия:

(37) В течение нескольких часов после видения страдалец ощущал чрезвычайную духовную радость (ЖСС 2, с. 21).

Высокая интенсивность эмоционального переживания может переходить в качественную характеристику. Так, отрицательно оцениваются в житиях отдельные чувства, например, ярость, и виды эмоциональных состояний - страсти:

(38) Иногда он видел открытый гроб, из которого вставал мертвец. Этим привидениям о. Серафим не поддавался, но прогонял их силой крестного знамения. Тогда враг стал нападать на него с еще большей яростью. Он поднимал подвижника на воздух и с такой силой ударял его об пол, что кости могли бы быть сломаны, если бы не охранявшая его благодать (ЖСС 2, с. 18);

(39) Имея умъ, очищенный отъ страстей, онъ неоднократно удостоивался духовныхъ видњній (ЖСС 1, с. 10);

(40) Под руководством сего богопросвещенного старца отец Леонид обучался науке из наук и искусству из искусств - умному монашескому деланию, подвигу непрестанной молитвы и противоборства страстям, и достиг просвещения духовного (ЖСЛ 2, с. 38).

Существительное ярость имеет в современном русском языке значение «сильный гнев, бешенство» (БТСРЯ, с. 1533), сходное со значением, закрепленным в языке XIX в. «сильный гнев, запальчивость» (СЦСиРЯ, т. 4, с. 484), и номинирует длительное эмоциональное состояние аффективной природы, отрицательное чувство высокой интенсивности. В современном русском языке существительное ярость входит в один синонимический ряд со словами гнев, раздражение, бешенство. При этом гнев обозначает состояние и чувство сильнейшего негодования и возмущения, вызванные кем-, чем-либо; раздражение - состояние недовольства и возмущения; ярость - сильнейший гнев, крайнюю степень негодования; бешенство сильнейший гнев, проявляющийся с необузданной силой (СС, т. 1, с. 237).

Ярость отличается от гнева не только большей степенью интенсивности, но и предельным характером, близким к бессознательному состоянию - животной ярости, ср.: Когда он проезжал по глухой лесной дороге, на него напал волк, который, вскочив в сани, с яростью набросился на молодого приказчика и вырвал из его ноги кусок мяса (ЖСЛ 2, с. 36). В связи с этим носителями данного переживания в житиях часто являются либо люди, одержимые дьяволом, либо животные, связанные с дьявольскими силами, либо сам дьявол.

Таким образом, эмотивы в анализируемых текстах используются прежде всего для характеристики людей (чаще - подвижника, но также и священнослужителей, мирян). Сохраняемые традиции в их употреблении связаны с выбором той или иной лексемы, который зависит как от ее семантики, так и от ее «типового» контекстуального окружения; с закреплением определенного круга лексем (преимущественно с семантикой положительных эмоций) за описанием подвижника.

\section{Глаголы восприятия как средство описания подвижника}

Образ святого создается в житийных текстах с помощью разных языковых средств: наряду с эмотивной лексикой значимыми являются глаголы восприятия, поскольку в их семантике отражены особенности получения информации об окружающем мире с помощью 
органов чувств и связь этого процесса с осмыслением данной информации.

Глаголы восприятия мы рассматриваем как единицы, формирующие отдельную лексико-семантическую группу, которая входит в состав лексико-семантического поля 'действие' (см. об этом: [Семантика древнерусского глагола..., 2015, с. 242]).

Специфика перцепции как вида деятельности определяется несколькими факторами, прежде всего активностью / пассивностью воспринимающего субъекта и каналом получения информации. В связи с этим перцептивные глаголы анализируются нами с учетом их дифференциации по разным основаниям. В зависимости от характера воспринимающего субъекта (активный / пассивный) выделены глаголы преднамеренного (в другой терминологии - целенаправленного, контролируемого) и непреднамеренного (нецеленаправленного, неконтролируемого) восприятия. В зависимости от определяемого каналом получения информации способа восприятия выделены подгруппы глаголов с общим значением восприятия, зрительного восприятия, слухового восприятия, обоняния и осязания (подробнее об этом: [Семантика древнерусского глагола..., 2015, с. 241-244]).

Для создания образа старцев в анализируемых текстах используются единицы, относящиеся к трем из названных подгрупп, глаголам с общим значением восприятия, зрительного и слухового восприятия. Перцептивные глаголы употребляются агиографами также в повествовании о других священнослужителях и мирянах, приходивших к старцам за исцелением от физических и душевных недугов, однако их описание подчинено другой цели - созданию образа подвижника.

Использование перцептивных глаголов в исследуемых нами житиях обнаруживает общность, которая проявляется в характере значения лексической единицы (прямое или переносное).

Глаголы с общим значением восприятия, не содержащие в семантике указания на канал получения информации об окружающем мире, обозначают «синкретичное» восприятие, которое всегда осуществляется пассивным субъектом. Глаголы этой подгруппы используются для описания как преподобных, так и людей, приходивших к ним за помощью и получивших в дальнейшем исцеление по молитвам старцев. Специфика употребления таких единиц обнаруживается в том, что в рассматриваемых текстах они реализуют непрямые значения, ставшие результатом семантических изменений в их смысловых структурах, например:

(41) Господь укреплял его: он не чувствовал утомления, не нуждался почти в отдыхе, часто забывал о пище и питье (ЖСС 2, с. 11);

(42) съ первыхъ чиселъ сентября о. Леонид началь ослаб пять: чувствоваль сильную боль въ правомъ боку, въ груди скопленіе мокротъ, и въ животь большую затвердтлость (ЖСЛ 1, с. 172);

(43) Таковая истина его [о. Леонида] словъ и кротость смягчили мое сердце, и я со слезами просил у него прощения, и чувствоваль вполнь незлобіе его (ЖСЛ 1, с. 116);

(44) Она была больна, чувствовала ужасную тоску и от болезни не могла в постные дни кушать пищи, положенной уставом Церкви (ЖСС 2, с. 41).

Употребляясь в сочетании с существительными утомление, незлобие, боль, с возвратным местоимением себя, глагол чувствовать обозначает не получение информации о внешнем мире с помощью органов чувств, но мыслительные (чувствоваль незлобіе; чувствовала ужасную тоску) и физиологические (чувствоваль сильную боль) процессы, замкнутые в сфере субъекта.

Глаголы зрительного восприятия могут номинировать как непреднамеренное, так и преднамеренное получение информации с помощью органов зрения и реализуют в изучаемых житийных текстах прямые и переносные значения.

Непреднамеренное зрительное восприятие выражено в тексте лексемами видать (увидать), видеть (увидеть), замечать (заметить):

(45) Какъ скоро увидаль меня батюшка о. Леонидъ, то съ любовною улыбкою благословиль (ЖСЛ 1, с. 108);

(46) Никто никогда не видел святого возмущенным (ЖСЛ 2, с. 46);

(47) Временами он [о. Серафим] видел Ангелов, сослужащих братии и воспевающих (ЖСС 2, с. 13);

(48) Увид女въ его братія въ такомъ жалкомъ положеніи, ужаснулись и спрашивали, что съ нимъ случилось? (ЖСС 1, с. 17); 
(49) Как только увидела Преподобного, тотчас упала перед ним и бес громко закричал в ней (ЖСЛ 2, с. 46).

Глагольные словоформы функционируют в сочетании с существительными и местоимениями, обозначающими объекты, которые могут быть восприняты с помощью зрения (святой, Преподобный, я и др.), эксплицируя процесс зрительного восприятия, непреднамеренность которого подтверждается грамматически - глагол управляет формой вин. п. без предлога (или род. п. без предлога при отрицании).

Отдельного рассмотрения требует глагол замечать (заметить), зафиксированный в современном житийном тексте в следующем употреблении:

(50) Приходя иногда к о. Серафиму, они заставали его в таком положении [он стоял неподвижно, углубясь в созерцание тайн духовных], он их не замечал и, иногда прождав перед ним около часу, они так и уходили, не замеченные им (ЖСС 2, с. 14).

Данный глагол многозначен: «1. Увидеть, обнаружить; обратить внимание на что-л., подметить; 2. Запомнить по каким-либо признакам; приметить; 3. Сказать; вставить в разговор замечание» (БТСРЯ, с. 333). Употребление глагола в конструкции с местоимением, указывающим на конкретный объект, в форме род. п. без предлога ( $и x$ не замечал), а также использование контекстуального локального уточнителя перед ним позволяют сделать вывод о реализации в данном случае прямого значения - «восприятие зрением».

Глаголы непреднамеренного зрительного восприятия используются в исследуемых текстах не только в прямых, но и в переносных значениях, связанных с разного рода мыслительными процессами (как правило, эти значения закреплены в лексической системе и зафиксированы в толковых словарях). Так, глагол видеть (увидеть) употреблен в сочетании с существительным сон, например:

(51) Прохор увидел во сне Пресвятую Богородицу, которая обещала посетить и исцелить его (ЖСC 2, с. 5);

(52) Марфа Толстова ... была совершенно слепая четырнадцать лет и видела во сне старичка [о. Серафима], повелевшего ей побывать в Сарове, где она получит исцеление (ЖСС 2, с. 54);
(53) Въ этой скорби она два раза видьла во снł, что старець даль ей кусокъ хльба (ЖСЛ 1, с. 131).

Глаголы зрительного восприятия в переносных значениях отмечены и в следующих контекстах:

(54) Съ особенною неусыпностію заботился онъ о тьхъ, въ коихъ видњлъ расположеніе къ добру, утверждалъ ихъ сов тами, наставленіями, указаніемъ пути спасенія, и возбуждалъ ихъ къ любви любовію своею (ЖСС 1, с. 27);

(55) Настоятель, видя твердость его духа, оставилъ его при его желаніи, и онъ возвратился въ свою келлію (ЖСС 1, с. 18);

(56) За такой образъ д вергался многимъ нареканиіямъ, и даже нькоторыя духовныя особы, по слухамъ, вид ъли въ немъ самочиніе и желаніе учить (ЖСЛ 1, с. 59);

(57) Какія перемъны ни происходили въ положеніи о. Леонида, онъ все принималъ равнодушно. «...Не вижу таковыхъ скорбей, которыя были бы невыносимы...» (ЖСЛ 1, с. 161);

(58) С особенной любовью встречал он тех, в ком видел желание исправиться, искреннее раскаяние в грехах (ЖСС 2, с. 26).

Использование глагола видеть в сочетании с абстрактными существительными (расположение, твердость, самочиние, желание, скорбь) исключает возможность обозначения им зрительного восприятия объекта, обязательным признаком которого является конкретность. В приведенных контекстах рассматриваемый глагол номинирует не процесс получения информации об окружающем мире, а мыслительный процесс.

В житиях старцев употреблены и глаголы преднамеренного зрительного восприятия, среди них наиболее широко представлены взглянуть, посмотреть:

(59) Преподобный отец наш, взглянув на него, сказал: «Эка остолопина идет!» (ЖСЛ 2, с. 43);

(60) Отец Серафим, благословляя прочихъ, взглянул и на меня и дал мне знак рукой, чтоб я прошел к нему (ЖСС 2, с. 37);

(61) «Вот, началь свою рьчь о. Леонид, посмотрите на этого челов Һка...» (ЖСЛ 1, с. 62);

(62) Старецъ, посмотрЊвъ на него, и грозясь пальцемъ, промолвилъ: «охъ, Ванюшка, не передъ добромъ ты смиряешься» (ЖСЛ 1, с. 126);

(63) Посмотрњвши на предстоящихъ учениковъ своихъ, онъ поднялъ правую руку, перекре- 
стился самъ, потомъ благословилъ ихъ всехъ, и опять взглянуль на икону Божіей Матери, какъ будто прося ученикамъ своимъ Ея заступленія (ЖСЛ 1, с. 175).

Как показывают примеры, глаголы преднамеренного зрительного восприятия использованы в прямых значениях, при этом преднамеренность эксплицируется грамматически - глагол управляет формой вин. п. с предлогом на.

Глаголы слухового восприятия, подобно глаголам зрительного восприятия, обозначают в исследуемых текстах как непреднамеренное, так и преднамеренное получение информации и реализуют преимущественно прямые значения.

Непреднамеренность слухового восприятия выражена глаголами слушать, сльхать, сльишать (выслушать, усльишать), которые используются агиографами при описании святых, других священнослужителей и мирян. Например:

(64) Наканун какого-либо праздника или воскреснаго дня всегда приходилъ онъ въ монастырь, гдњ слушаль вечерню, всенощное бдњниіе и въ самый праздникъ пріобщался Святых Таинъ (ЖСС 1, с. 12);

(65) старецъ, часто углубляясь въ молитву, забывал о немъ, не слыхалъ его объясненій, и н亡сколько разъ заставляль его повторять одно и тоже (ЖСЛ 1, с. 100);

(66) Иноки, жившие в лесу, слыхали от него [о. Серафима] мудрые наставления (ЖСС 2, с. 17);

(67) Во время таковаго его уединенія многіе изъ братіи слышали его часто поющимъ Антифонъ (ЖСC 1, c. 24);

(68) Старецъ, выслушавъ все съ отеческою любовію, очень утьшил меня своею бесњдою (ЖСЛ 1, с. 86);

(69) Невольно или от стыда ученики иногда хотели утаить от Старца свои помыслы, но Преподобный, выслушав исповедь, сам высказывал все утаенное (ЖСЛ 2, с. 43);

(70) Однажды во время молитвы о. Серафим услышал вой зверей за стенами кельи (ЖСС 2, с. 17).

В сочетании с существительными (вечерня, объяснение, наставление, исповедь) или местоимениями (все), обозначающими услышанное, а также с существительными, номинирующими звуки (вой), глаголы слухового восприятия реализуют прямое значение.
Итак, глаголы восприятия используются в анализируемых житийных текстах для описания святых, других священнослужителей и мирян. Из выделенных в зависимости от способа получения информации подгрупп перцептивных глаголов в исследуемом материале представлены подгруппы глаголов с общим значением восприятия, зрительного и слухового восприятия. Если глаголы слухового восприятия преимущественно реализуют прямые значения, то глаголы с общим значением восприятия и глаголы зрительного восприятия не только прямые, но и переносные значения, ставшие фактом языковой системы.

\section{Заключение}

В результате исследования агиографических текстов установлено, что традиция создания преподобнических житий развивается, о чем свидетельствует появление агиографического описания подвижников нового типа старцев. При создании их образа обнаруживаются изменения в агиографической схеме отсутствие реализации отдельных топосов, переосмысление некоторых топосов, появление дополнительных топосов.

Сопоставление жизнеописаний одного святого, относящихся к синодальному и современному периодам, выявило на фоне общей сюжетной основы наличие вариантов в разработке отдельных топосов, при этом говорить о постепенном свертывании житийного канона нельзя, поскольку выбор того или иного варианта агиографической схемы, повидимому, определяется в большей мере интенциями автора, чем общими тенденциями развития жанра.

В создании образа подвижника важную роль играет лексика, раскрывающая его внутренний, «незримый», мир (эмотивные глаголы) и характеризующая способы его взаимодействия с миром внешним, «зримым» (перцептивные глаголы).

Рассмотрение лексики эмоций позволило выявить константные черты представления святого: зависимость выбора лексемы от статуса характеризуемого субъекта, значимость высокой интенсивности эмоционального переживания и его причины; связь между количественными характеристиками эмоции и ее оцен- 
кой (эти черты наблюдаются и в житийных текстах более ранних периодов).

Обращение к анализу глаголов восприятия позволило выявить значимые для описания преподобного перцептивные процессы и установить закономерности их языковой экспликации. В анализируемых житийных текстах доминируют глаголы зрительного восприятия. Кроме того, представлены глаголы с общим значением восприятия и глаголы слухового восприятия. Лексические единицы, выражающие обоняние и осязание, в текстах не отмечены, что свидетельствует о нерелевантности полученной таким образом информации для создания образа святого. Глаголы восприятия используются, как правило, в прямых значениях, отражая при этом специфику протекания перцепции, зависящую от характера субъекта. Важная для создания образа преподобного связь перцептивных и мыслительных процессов реализуется посредством переносных значений глагольных единиц.

\section{ПРИМЕЧАНИЕ}

${ }^{1}$ Исследование выполнено при финансовой поддержке Российского фонда фундаментальных исследований в рамках научного проекта № 17-3401009-ОГН «Отражение представлений о нравственном идеале в языке русской оригинальной агиографии XVIII-XX веков».

\section{СПИСОК ЛИТЕРАТУРЫ}

Аверина С. А., 1991. К характеристике художественно-изобразительных средств в русской агиографии XVI в. // История русского языка: Лексикология и грамматика. Казань : Изд-во Каз. ун-та. С. 9-15.

Адрианова-Перетц В. П., 1964. Задачи изучения «агиографического стиля» Древней Руси // Труды Отдела древнерусской литературы / отв. ред. Д. С. Лихачев. М. ; Л. : Наука. Т. 20 : Актуальные задачи изучения русской литературы XI-XVII веков. С. 41-71.

Бёш-Гайано С., 2011. Изучение житий святых и историография // Русская агиография: Исследования. Материалы. Публикации / отв. ред. Т. Р. Руди, С. А. Семячко. СПб. : Изд-во «Пушкинский Дом». Т. II. С. 503-516.

Владимир (Швец), архимандрит, Сорочан С. Б., 2015. Введение в агиографию. Харьков : Майдан. $264 \mathrm{c}$.
Дмитриева Е. Г., 2011. Характерологическая функция эмотивной глагольной лексики в древнерусских и старорусских текстах // Слово в языке и тексте : Сборник статей к 85-летию со дня рождения Софии Петровны Лопушанской. Волгоград : Волгоградское научное издательство. С. 42-55.

Живов В. М., 1994. Святость. Краткий словарь агиографических терминов. М. : Гнозис. 112 с.

Жития новомучеников и исповедников..., 2005-2008. Жития новомучеников и исповедников Российских XX века / сост. игум. Дамаскин (Opловский) : в 9 т. Тверь : Булат.

Жития святых..., 1984. Жития святых : 1000 лет русской святости / собрала монахиня Таисия : в 2 т. 2-е изд., испр. и доп. Jordanville, N.Y. : Holy Trinnity Russian orthodox monastery.

Карпов А. Ю., 2005. Православные святые и чудотворцы. М. : Вече. 304 с.

Ненароков Н., 2017. Оптинское старчество и его истоки // Преподобные старцы Оптинские. Жития и наставления. 2-е изд. Введенский ставропигиальный мужской монастырь Оптина пустынь. С. 5-31.

Руди Т. Р., 2006. О композиции и топике житий преподобных // Труды Отдела древнерусской литературы ; отв. ред. О. В. Творогов. СПб. : Дмитрий Буланин. Т. 57. С. 431-500.

Семантика древнерусского глагола..., 2015. Семантика древнерусского глагола: синхронно-диахронический аспект : коллектив. моногр. / О. А. Горбань, Е. Г. Дмитриева, М. В. Косова, И. А. Сафонова, Е. В. Терентьева ; отв. ред. Е. М. Шептухина. 2-е изд., доп. М. : Флинта : Наука. 352 с.

\section{ИСТОЧНИКИ}

ЖСЛ 1 - Жизнеописаніе Оптинскаго старца іеромонаха Леонида (въ схимњ Льва). М. : Типографія В. Готье, на Кузнецкомъ мосту д. Торлецкаго, 1876. С. 7-181.

ЖСЛ 2 - Житие преподобного Льва, старца Оптинского // Преподобные старцы Оптинские. Жития и наставления. Изд. 2-е. Введенский ставропигиальный мужской монастырь. Оптина пустынь, 2017. С. 35-50.

ЖСС 1 - Сказаніе о жизни и подвигахъ блаженныя памяти отца Серафима, Саровской пустыни іеромонаха и затворника. М. : Въ Университетской Типографіи, $1841.31 \mathrm{c.}$

ЖСС 2 - Житие преподобного Серафима Саровского чудотворца // Преподобный Серафим Саровський. Житче і повчання. К. : КиевоПечерська Успенська Лавра, 2013. С. 3-56. 


\section{СЛОВАРИ}

БТСРЯ - Большой толковый словарь русского языка / сост. и гл. ред. С. А. Кузнецов. СПб. : Норинт, 2000. $1536 \mathrm{c}$.

$C C-$ Словарь синонимов русского языка : в 2 т. / под ред. А. П. Евгеньевой. Л. : Наука, 1970-1971.

СЦСиРЯ - Словарь церковно-славянскаго и русскаго языка, составленный Вторымъ отдькленіемъ Императорской Академіи наукъ : в 4 т. СанктПетербургъ : Въ Типографіи Императорской Академіи наукъ, 1847.

\section{REFERENCES}

Averina S.A., 1991. On Characteristics of Literary and Descriptive Means in Russian Hagiography of the $16^{\text {th }}$ cen. Istoriya russkogo yazyka: Leksikologiya i grammatika [History of the Russian Language: Lexicology and Grammar]. Kazan, Izd-vo KGU, pp. 9-15.

Adrianova-Perets V.P., 1964. The Goals in Studies of Hagiographic Style of Ancient Rus. LikhachevD.S., ed. Trudy Otdela drevnerusskoy literatury. T. 20: Aktualnye zadachi izucheniya russkoy literatury XI-XVII vekov [Proceedings of the Department of Old Russian Literature. Vol. 20: Current Problems of Russian Literature Studies of the $11^{\text {th }}-17^{\text {th }} \mathrm{cc}$.]. Moscow; Leningrad, Nauka Publ., pp. 41-71.

Besh-Gayano S., 2011. Studies of Hagiographic Texts and Historiography. Rudy T.R., Semyachko S.A., eds. Russkaya agiografiya. Issledovaniya. Materialy. Publikatsii. Saint Petersburg, Pushkin Dom Publ., vol. 2, pp. 503-516.

Vladimir (Schvets), archimandrite, Sorochan S.B., 2015. Introduction to Hagiography. Kharkov, Maidan Publ. 264 p.

Dmitrieva E.G., 2011. On Characteristic Function of Emotive Verbal Lexis in Ancient and Old-Russian Texts. Slovo v yazyke i tekste: Sbornik statey $k$ 85-letiyu so dnya rozhdeniya Sofii Petrovny Lopushanskoy. Volgograd, Volgogradskoe nauchnoe izd-vo, pp. 42-55.

Zhivov V.M., 1994. Holiness. A Short Dictionary of Hagiographical Terms. Moscow, Gnozis Publ. $112 \mathrm{p}$.

Hegumen Damaskin (Orlovsky), 2005-2008. The Lives of New Martyrs and Confessors of Russia of the $20^{\text {th }}$ Cenntury: in 9 vols. Tver, Bulat Publ.

Nun Taisiya, 1984. The Life of Holy Fathers: 1000 years of Russian Sanctity: in 2 vols. Jordanville;
New York, Holy Trinity Russian orthodox monastery.

Karpov A.Yu., 2005. Orthodox Saints and WanderMakers. Moscow, Veche Publ. 304 p.

Nenarokov N., 2017. Optina Eldership and its Roots. Prepodobnye startsy Optinskie. Zhitiya $i$ nastavleniya. Eastern Orthodox Monastery Optina Pustyn, pp. 5-31.

Rudy T.R., 2006. On Composition and Theme of Hagiography. Tvorogov O.V., ed. Trudy Otdela drevnerusskoy literatury. Saint Petersburg, Dmitry Bulanin Publ., vol. 57, pp. 431-500.

Gorban O.A., Dmitrieva E.G., Kosova M.V., Safonova I.A., Terentyeva E.V. (eds.), 2015. Semantics of the Old Russian Verb: Synchronous and Diachronic Aspect: Monograph. Moscow, Flinta; Nauka Publ. 352 p.

\section{SOURCES}

Life of Opina Elder Hieromonch Leonidas (Schemamonk Leo). Moscow, Tipographia V. Gotije, na Kuznetskom mostu d. Torletskago, 1876, pp. 7-181.

Life of Venerable Leo, Optina Elder. Prepodobnye startsy Optinskie. Zhitiya i nastavleniya. Eastern Orthodox Monastery Optina Pustyn, 2017, pp. 35-50.

Story about the Life and Feats of Saint Seraphim of Sarov, Hieromonch and Ascetic of Sarov Hermitage. Moscow, V Universitetskoy Tipographii, $1841.31 \mathrm{p}$.

Life of Holy Saint Seraphim of Sarov, the WonderMaker. Prepodobnyy Serafim Sarovskiy. Zhitiye i povchannya. Kiev, Kievo-Pecherska Uspenska Lavra, 2013, pp. 3-56.

\section{DICTIONARIES}

Kuznetsov S.A. (ed.). Great Explanatory Dictionary of the Russian Language. Saint Petersburg, Norint Publ. 2000. 1536 p.

Evgenyeva A.P. (ed.). The Dictionary of Synonyms in the Russian Language: in 2 vols. Leningrad, Nauka Publ. 1970-1971

Dictionary of the Church Slavonic and Russian language, compiled by the Second Department of the Imperial Academy of Sciences: in 4 vols. Saint Petersburg, V Tipografii Imperatorskoy Akademii nauk, 1847. 


\section{Information about the Authors}

Evgeniya G. Dmitrieva, Candidate of Sciences (Philology), Associate Professor of Department of Russian Philology and Journalism, Volgograd State University, Prosp. Universitetsky, 100, 400062 Volgograd, Russia, eg_dmitrieva@volsu.ru, iryas@volsu.ru, https://orcid.org/0000-0001-5117-5677

Irina A. Safonova, Candidate of Sciences (Philology), Associate Professor of Department of Russian Philology and Journalism, Volgograd State University, Prosp. Universitetsky, 100, 400062 Volgograd, Russia, ia_safonova@volsu.ru, iryas@volsu.ru, https://orcid.org/0000-0003-1103-7434

\section{Информация об авторах}

Евгения Геннадьевна Дмитриева, кандидат филологических наук, доцент кафедры русской филологии и журналистики, Волгоградский государственный университет, просп. Университетский, 100, 400062 г. Волгоград, Россия, eg_dmitrieva@volsu.ru, iryas@volsu.ru, https://orcid.org/ 0000-0001-5117-5677

Ирина Александровна Сафонова, кандидат филологических наук, доцент кафедры русской филологии и журналистики, Волгоградский государственный университет, просп. Университетский, 100, 400062 г. Волгоград, Россия, ia_safonova@volsu.ru, iryas@volsu.ru, https://orcid.org/ 0000-0003-1103-7434 